Effects of Sibling Competition on Family Firm Succession: A Game Theory Approach Shital Jayantilal ${ }^{1}$, Sílvia Ferreira Jorge ${ }^{2}$, Tomás M. Bañegil Palacios ${ }^{3}$

\author{
${ }^{1}$ Cátedra de la Empresa Familiar - Universidad de Extremadura \\ shitaljayantilal@hotmail.com - Corresponding Author
}

\footnotetext{
${ }^{2}$ Universidade de Aveiro- Departamento de Economia, Gestão e Engenharia Industrial / GOVCOPP sjorge@ua.pt

${ }^{3}$ Universidad de Extremadura - Departamento de Dirección de Empresas y Sociologia tbanegil@unex.es
}

\title{
Effects of Sibling Competition on Family Firm Succession: A Game Theory Approach
}

\begin{abstract}
Strong interconnections between family and business which are innate to family firms can prove to be the source of conflict. Of all conflicts, those between family members and especially between siblings erode the family's harmony and can risk the firm's continuity. The passing of the family firm's control from the founders to the next generation is a critical stage for the family firm and can be a catalyst for conflict. This article extends the use of game theory in family firm succession to explicitly include the noneconomic factors related to the family dimension, focusing on the emotional cost of conflict resulting from sibling competition. The results show that this cost is fundamental in terms of successor selection. The article shows that the collaborative family outcome, which results from family members cooperating and acting as
\end{abstract}


a unit, is better in promoting firm intergenerational succession and ensuring that the founder's preferred child is appointed successor.

Keywords: Conflict; Sibling Competition; Family Firm; Succession; Game Theory; Collaborative Family Outcome

\section{INTRODUCTION}

The overlap between family and the business, each with its own issues and possible conflicts, means that the family firm is especially exposed to conflict. Although not all family firms are plagued with conflict, conflict has the potential to harm the firm's performance, stability and even its continuity and simultaneously threatens family cohesion and harmony. Moments of change in the family firm or difficulties in the family can trigger or exasperate conflict in the family firm. In this context management succession of the family firm can be seen as a potential conflict catalyst.

The succession process in the family firm can lead to siblings competing for the executive control of the firm which can result in conflict, with repercussions on both the family and business dimensions. An extreme and epic example of such conflict between siblings was the case of the succession process at Reliance Industries. The founder, Dhirubhi Ambani passed away in 2002 without naming his successor or leaving a will. His elder son, Mukesh, was appointed chairman and his younger son, Anil, the vice-chairman. Soon after power struggles began with one brother trying to push the other out of the firm and rapidly the rivalry escalated. Their mother stepped in to solve the conflict between the two brothers by promoting the demerger of the conglomerate in 2005. Mukesh retained Reliance Industries, including oil and gas, petrochemicals, and textiles operations, while Anil took over Reliance Infocomm, Reliance Capital and Reliance Energy. However, the fighting continued until 2010 when their mother, made both her sons sign a noncompeting agreement to put an end to years of legal fights. Since 
2013 there have been signs that two of the richest and most successful business men in India have began to put their differences behind them and rekindle their family ties.

Although the business arena has witnessed various instances of family firm successions beset with dispute between brothers ${ }^{1}$ this is not always the case. However, given the negative impact that sibling conflict can have on the firm and the family it is imperative to improve the understanding of the role it plays in the context of family firm succession. We respond to this need by expanding the limited literature on conflict in family firms to include the impact of sibling competition on the choice of the successor. We focus on the sibling competition which arises from the competitive behavior of siblings driven by the desire to become the new head of the family firm.

We further contribute by extending the use of game theory in family firm succession. Game theory is the study of decision making by various rational players where decisions made by each player has repercussions on the outcomes of the other players. The strategic interdependence is the essence of game theory. The selection of the successor for the family firm is essentially a strategic decision, involving the founder and the potential successors. The mathematic foundations of game theory provide a rigorous and objective analysis on one of the most demanding challenges that the family firm faces.

We contribute to advancement of game theory as an important tool in family firm succession analysis as it rationalizes the underlining process more deeply. Additionally, by including the emotional factors in our analysis, we enable a better understanding of the behaviors and motivations of all involved, highlighting the impact on successor selection.

In our game we explicitly include the emotional cost of conflict which can result from sibling competition. Our Nash subgame perfect results show that the emotional cost of conflict resulting from sibling competition plays a key role on successor outcome. That cost directly influences the propensity of the founder's preferred child being successor.

${ }^{1}$ For more cases refer to Grant, G. \& Nicholson, N., (2008), Family Wars: Classic Conflicts in Family Business and How to Deal with Them. London: Kogan Page. 
Lastly, we extend the notion of collaborative family, presented by Dyer (1986) and apply it our modeled game, in order to study which successor outcome would be optimal for the family, as a unit. That result, which we refer to as the collaborative family outcome, increases the propensity of intergenerational succession of the family firm being secured, when compared to the subgame perfect Nash equilibrium. Additionally, our findings highlight that when all the members collaborate this augments the propensity of the founder's preferred child being the successor.

The paper begins with a review of the relevant literature which is then followed by the presentation of our game and discussion of the results. We finalize by reflecting on the findings, and suggest future avenues of research.

\section{INTERGENERATIONAL FAMILY FIRM SUCCESSION}

The family is a key part of the firm and the firm is also important to the family (Pieper \& Klein, 2007). The overlap of the family and the business sphere is a distinctive characteristic of the family firm. Thus value creation in the family firm is seen as a sum of both economic and noneconomic goals (Klein \& Kellermanns, 2008; Gómez-Mejía, Núñez-Nickel, \& Guiterrez 2001; Gómez-Mejía, Haynes, Nuñez-Nickel, Jacobson, \& Moyano-Fuentes, 2007). Distelberg \& Sorenson (2009) argue that the family firm pursues goals linked to the business (economic) and others related to the family (emotional). The underlining goals determine the way the founder (and management teams) makes decision.

\section{Successor attributes}

The choice of successor is a key strategic decision. When making this choice the founder takes into consideration potential successor's interpersonal skills (Motwani, Levenburg, Schwarz \& Blanson, 2006); strategic thinking (Cater \& Justis, 2009); capabilities in fields of accounting, human resource management, operational management (DeNoble, Ehrlich \& Singh, 2007); communication skills and the power to motivate, influence and inspire people (Waldman, Siegel 
\& Javidan, 2006). Other than these aspects, which encompass the leadership ability of the potential successor his family orientation is also considered. Family orientation, introduced by Lumpkin, Martin and Vaughn (2008) is an individual measurement of the "familiness" construct, introduced by Habberson and Williams (1999), and indicates the extent the child perceives and values family involvement in the family business

A founder when choosing the successor will take into account the leadership ability but also the potential successor's family orientation. He will weigh both these aspects according to his preference which is affected by, among other factors, the cultural setting (Jayantilal, Palacios \& Jorge, 2015).

\section{Emotional and Economic Factors}

The family firm has been identified as a fertile field for conflict (Harvey \& Evans, 1994) due to the influence of the family in the firm (Sorenson, 1999). Sibling competition which occurs when siblings race against each other for the successor position in the family firm, can lead to affective conflict harming both the business and the family (Friedman, 1991). Conflict is a relevant emotional cost for all involved. The valuation in the family firm is the sum of the financial and the emotional value (Astrachan \& Jaskiewicz, 2008). The emotional value results from the interaction of the family and the firm in the family firm whereas the financial value is the traditional discounted cash flow valuation of the firm. The emotional value includes the emotional benefits net of the emotional costs. The main noneconomic benefits refer to continuity and legacy (Chrisman, Chua, Pearson \& Barnett, 2012) whereas the key emotional cost is the cost of conflict (Zellweger \& Astrachan, 2008). This emotional valuation is performed by all involved and is increased by their affective commitment.

The way the firm deals with critical issues and faces challenges can exasperate conflict. Managerial succession is critical for the family firm's continuity. Deciding on who will succeed is one of the most important challenges that the founder of the family firm faces. The way the 
process is handled, how expectations are managed, and how the final choice made can sparkle hostility in the family, especially among siblings.

Sibling rivalry is natural and to some extent exists in all family contexts. In extreme cases sibling rivalry can lead to the stagnation of the family firm succession process (Miller, Steier \& Breton-Miller, 2003) and the total failure of the succession process resulting in the dissolution (Avloniti, Iastridou, Kaloupis \& Vozikis, 2014) and disintegration (Griffeth, Allen \& Barnett, 2006) of the family firm.

\section{FAMILY FIRM SUCCESSION AND GAME THEORY}

The existing literature on family firm succession using game theory is quite disparate in terms of the role attributed to conflict between siblings. Some of the research emphasizes the successor choice and doesn't focus on conflict issues. As is the case of, Lee, Lim and Lim (2003) who studied the impact of the business's degree of idiosyncrasy and the ability of the potential successor on successor selection. They showed that families prefer to appoint a family member as successor, as opposed to an outsider, when the firm is a high idiosyncratic business. Bjuggren and Sund (2001) also used game analysis to study succession but focused on the role of legal and transactional costs on ownership succession. The impact of the legal context on the choice between a family and a professional manager to head a public firm, was analyzed by Burkat, Panunzi, and Shleifer (2003).

Blumentritt, Mathews and Marchisio (2013) present an introduction to the use of game theory to study succession in the family firm. In their game the children chose, simultaneously, to run to succeed their father in the firm, and then this was followed by the father appointing his successor. The child's desire to become the successor net of the cost of running for the position was the payoff function they considered for the children. The payoff of the father resulted from the weighed sum of the successor's desire and ability. Their findings showed that when both children ran for the position then the father would compare both their ability and desire and then make his choice. A founder who prefers a successor who really wants the job more than one 
who is more capable of maximizing the firm's potential but is not as interested, will opt for the child endowed with greater desire in detriment to the most able. The authors conclude that when both children run for the position this leads to conflict between the siblings and harms family harmony. Although they refer the importance of this emotional cost it is not explicitly included in the payoff functions of any of the players. This paper introduces the notion of Total Family/Firm Welfare, as the sum of the payoffs of all three players of the game, and shows that, when maximizing this welfare the outcome may differ from the equilibrium results.

Michael-Tsabari and Weiss (2013) defend that the players have a double objective: one related to the business sphere - managerial succession - and the other related to the family sphere avoiding tension and conflict. The role of conflict in their game is very important but they focus on father/son conflict and not conflict between siblings. They applied the Battle of the Sexes game to family firm succession. The outcomes of the players were ordered in terms of their preferences of moving forward with the succession and of avoiding tension and conflict. The authors emphasized the role of communication to ensure both players attained what they wanted without jeopardizing family harmony. Although, they addressed the issue of conflict, their game theoretic analysis did not involve sibling conflict nor did they define the payoff functions of each player.

Mathews and Blumentritt (2015) modelled a sequential-move tournament game where the children chose the level of effort to pursue the successor position. They identified the possibility of first-mover advantage and acknowledged situations which could lead to conflict but, once again, did not consider this emotional cost in the payoff functions.

More recently, Jayantilal, Palacios \& Jorge (2015), use a game theory approach to study the impact that culture has on successor selection. Their findings show that cultural alignment between both generations plays a fundamental role in securing intergenerational succession and promoting family harmony. They consider conflict but focus on the conflict which results from intergenerational cultural misalignment and not from sibling conflict. 
Most of the existing research on the use of game theory to study family firm succession recognizes conflict as being detrimental for both the family and the firm but none has, as yet, explicitly considered the emotional cost of conflict between siblings as a factor in the payoff functions of the players.

\section{SIBLING COMPETION AND SUCCESSOR SELECTION}

\section{Model Design}

Game theory is the study of decision making by various rational players where decisions made by a player have repercussions on the outcomes of the other players. The strategic interdependence is the essence of game theory. The selection of the successor for the family firm is essentially a strategic decision, involving the founder and the potential successors. The mathematic foundations of game theory, provides a rigorous and objective analysis on one of the most demanding challenges that the family firm faces.

This paper considers a sequential game of complete and perfect information, which means that the players move in sequence and are fully aware of the strategies available to each one, and observe all the moves before making theirs. These games are expressed in extensive form, as a tree, and are defined by: (i) the players of the game; (ii) when each player has to make a decision; (iii) what each player can decide at each point; and (iv) the payoff for the players resulting from each of the possible combination of chosen moves.

Figure 1 shows the game tree of our game which includes three players: the founder $(F)$, the elder child (E) and younger child $(\mathrm{Y})^{2}$. The first node represents the first move, which is played by E, who decides between running for the CEO position in the family firm and pursuing a career outside the family firm. Then $\mathrm{Y}$ decides whether or not to run for the position too and lastly $\mathrm{F}$ chooses the successor.

\section{Figure 1: Game Tree Representation}

\footnotetext{
${ }^{2}$ The aim is to improve the understanding of intergenerational succession so all other options such as selling the firm and/or hiring professional management have been excluded.
} 


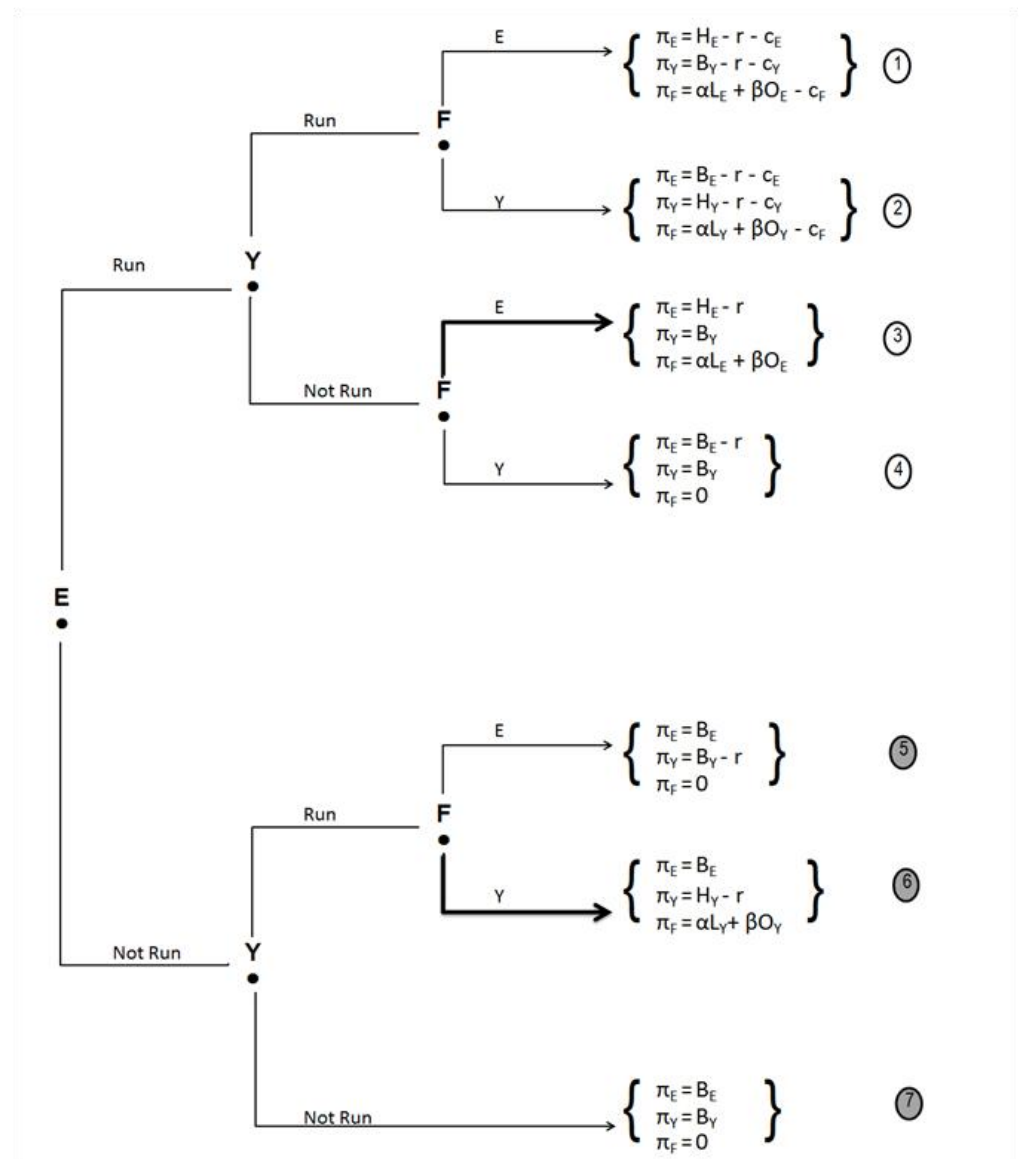

The payoffs of the players are numbered and presented at the end of the tree and include the variables considered in the game.

We start by focusing on the variables of the founder's payoff function. ${ }^{3}$

$\mathrm{L}_{\mathrm{i}}$ denotes the child's leadership skills and refers to the child's ability to maximize the firm's performance $\left(\mathrm{L}_{\mathrm{i}}>0 ; \mathrm{i}=\mathrm{E}, \mathrm{Y}\right)$. Under leadership skills we have considered all the necessary managerial skills, competencies and know-how that will allow the child to maximize the firm's value. Each child is defined by his business related ability and by the way he views the firm's family serving purpose. The child's level of family orientation $\left(\mathrm{O}_{\mathrm{i}}>0\right)$ indicates the extent the

\footnotetext{
${ }^{3}$ It is important to keep in mind that although the founder makes the decision, he/she is influenced by other family members (who may not even be in the firm) such as the spouse. In that sense, the payoff function of $\mathrm{F}$ should be understood as the payoff function of the family.
} 
child perceives and values family involvement in the family business (Lumpkin, Martin \& Vaughn, 2008). $\mathrm{L}_{\mathrm{i}}$ relates to the business dimension whereas $\mathrm{O}_{\mathrm{i}}$ refers to the family dimension. The extent a founder values the business sphere is given by $\alpha(\alpha>0)$ whereas $\beta$ refers to the value he attributes to the family sphere $(\beta>0)$. The founder's payoff is the weighed sum of both the family and the business related attributes of his successor.

The value each child attributes to being successor is also a sum of financial (i.e. wages) and emotional benefits. The emotional benefits relate, for instance, to the importance each child gives to legacy. The children value heading the firm, given by $H_{i}\left(H_{i}>0\right)$ but sustain a cost of running for the position, given by $r,(r \geq 0) .{ }^{4}$ We assume that the value they place for heading the firm surpasses the cost they incur for running for the position $\left(\mathrm{H}_{\mathrm{i}}>\mathrm{r}\right)$. The children also take into consideration their career options outside the family firm. $B_{i}\left(B_{i}>0\right)$ refers to the payoff the child obtains from his best career option outside the family firm (net of any costs he might incur in securing it). Sibling competition refers to the situation when both the children run for the top position in the family firm. This can lead to affective conflict between the siblings. Given the negative impact that sibling conflict has it is a relevant emotional cost which each child registers in their payoff functions, according to how much they are affected by that conflict. The sibling conflict has a negative spill over effect on family harmony so it is an emotional cost which is registered in F's payoff function. The cost of conflict is represented by $c_{j}\left(c_{j} \geq 0 ; j=F, E, Y\right)$. We have considered these emotional costs as independent. ${ }^{5}$

The emotional factors relating to the value the children place in heading the family firm $\left(\mathrm{H}_{\mathrm{i}}\right)$ and the cost of conflict $\left(\mathrm{c}_{\mathrm{j}}\right)$ are influenced by the affective commitment to the firm and the family, respectively. The greater that affective commitment is the higher those values will tend to be.

Table 1: Summary of all the variables of the game

\footnotetext{
${ }^{4}$ Different costs of running for each child imply no significant differences on the conclusions but add complexity in terms of results.

${ }^{5}$ Assuming that $\mathrm{c}_{\mathrm{F}}, \mathrm{c}_{\mathrm{Y}}$ and $\mathrm{c}_{\mathrm{E}}$ are correlated just adds complexity to the analysis but has no significant impact in terms of outcomes
} 


\begin{tabular}{|c|c|c|c|}
\hline Variables & Represents & $\mathrm{i}=\{\mathrm{E}, \mathrm{Y}\} \mathrm{j}=\{\mathrm{F}, \mathrm{E}, \mathrm{Y}\}$ & Conditions \\
\hline $\mathrm{L}_{\mathrm{i}}$ & Leadership Skills - Child's ability to head the family firm & & $\mathrm{L}_{\mathrm{i}}>0$ \\
\hline $\mathrm{O}_{\mathrm{i}}$ & Family Orientation - Extent child values family serving attribute of the firm & & $\mathrm{O}_{\mathrm{i}}>0$ \\
\hline$\alpha$ & Degree Father values the business sphere of the family firm & & $\alpha>0$ \\
\hline$\beta$ & Degree Father values the family sphere of the family firm & & $\beta>0$ \\
\hline $\mathrm{H}_{\mathrm{i}}$ & Value the child places in becoming successor and heading the family firm & & $\mathrm{H}_{\mathrm{i}}>0$ \\
\hline$B_{i}$ & Value the child places in his best career option outside the family firm & & $B_{i}>0$ \\
\hline$c_{j}$ & Emotional cost resulting from sibling rivalry & & $c_{j} \geq 0$ \\
\hline $\mathrm{r}$ & Cost of running for top position & & $\mathrm{H}_{\mathrm{i}}>\mathrm{r} \geq 0$ \\
\hline
\end{tabular}

This game has seven possible outcomes each with different payoffs for each of the possible game paths numbered in the far right of the tree. For instance, when E runs for the position, and $\mathrm{Y}$ also runs for the position and $\mathrm{F}$ chooses $\mathrm{E}$, this set of decisions are identified as path 1, and the resulting payoffs of the players are: $\pi_{E}=H_{E}-r-c_{E}, \pi_{Y}=B_{Y}-r-c_{Y}$ and $\pi_{F}=\alpha L_{E}+\beta O_{E}-c_{F}$.

\section{Results \& Discussion}

In a sequential game, the game tree allows the visualization of the course of the game and should be read from left to right. To reach the subgame perfect Nash equilibrium solution, for sequential games with perfect information, backward induction should be used, i.e. the game should be solved from right to left. This technique warrants each player to look ahead and think backwards, before making his decision. The underlining logic is that each player should figure out how each of the others will react to his move, and how he will respond to that, and so on, as a result he should anticipate the different players' reactions to his move and consider this when making his decision (Kreps, 1990).

Using backward induction and focusing on the top part of the tree, when $\mathrm{E}$ has decided to run and $\mathrm{Y}$ also decides to run, and starting at the terminal node where $\mathrm{F}$ is called to play, he chooses between his children who to appoint his successor. He compares his payoffs resulting from path 1 and path 2, and will opt for whichever maximizes his payoffs. ${ }^{6}$ It is when both $\mathrm{E}$ and $\mathrm{Y}$ compete for the position that $\mathrm{F}$ needs to choose between them. If one of the children was endowed with greater leadership skills and greater family orientation then he would be the chosen one. It is when both have different levels that $\mathrm{F}$ needs to consider those differences in light of his preference for the family or business sphere of the family firm. It is the founder's

\footnotetext{
${ }^{6}$ If the founder is indifferent between both children then he will opt for the elder.
} 
preference that determines how he chooses between his competing children. A business-first type of founder tends to value leadership skills relatively more than family orientation, on the contrary a family-first type will value family orientation relatively more.

He will opt for $\mathrm{E}$ if $\alpha \mathrm{L}_{\mathrm{E}}+\beta \mathrm{O}_{\mathrm{E}-} \mathrm{c}_{\mathrm{F}}>\alpha \mathrm{L}_{\mathrm{Y}}+\beta \mathrm{O}_{\mathrm{Y}-} \mathrm{c}_{\mathrm{F}}$. This condition gives the exact mathematical condition for $\mathrm{E}$ to be selected. This can be seen as $\mathrm{E}$ being preferred, when $\mathrm{F}$ is relatively more inclined to value leadership skills to family orientation, i.e. $\alpha>k \beta ; k=\left(O_{Y}-O_{E}\right) /\left(L_{E}-L_{Y}\right)$, else he will opt for Y.

Now focusing on the node, where $\mathrm{F}$ is called to play, when $\mathrm{E}$ has decided to run and $\mathrm{Y}$ has decided not to run for the position (refers to path 3 and 4), he will appoint E. As the assumption is that the F values passing on the firm's control to his children, his payoff is higher when he appoints E as successor (path 3). Path 4 will never be played as $\mathrm{F}$ will always prefer this option (marked with thicker line in the game tree).

If $\mathrm{F}$ relatively values leadership skills more than family orientation $\left(\left(\right.\right.$ for $\alpha>k \beta ; \mathrm{k}=\left(\mathrm{O}_{\mathrm{Y}}-\mathrm{O}_{\mathrm{E}}\right) /$ $\left(L_{E}-L_{Y}\right)$ ), when both $E$ and $Y$ compete for the position, he will opt for $E$ (path 1). The younger sibling anticipates this and prefers not to run as this maximizes his payoffs, so path 3 will be chosen.

When $\mathrm{E}$ does not run and $\mathrm{Y}$ runs for the CEO position in the family firm, then $\mathrm{F}$ will appoint $\mathrm{Y}$ as his payoff resulting from path 6 is higher than that resulting from path 5. Path 5, like path 4 , will never be played as path 6 is always preferred (marked with a thicker line in the game tree).

Continuing to move backwards in the game, $\mathrm{Y}$ must decide what to do when $\mathrm{E}$ decides not to run. He will choose the path which enables him to maximize his payoffs. Y will run for the top position (path 6) if his payoff is greater than his payoff for pursuing his career outside the family firm (i.e. $\mathrm{H}_{\mathrm{Y}}-\mathrm{r}>\mathrm{B}_{\mathrm{Y}}$ ) and in that case intergenerational succession will not be secured (path 7). ${ }^{7}$ The two plots on the left in Figure 2 summarize all the above conditions considering a

\footnotetext{
${ }^{7}$ If any child is in indifferent between running or not running for the successor position, he will opt to run for the position
} 
founder who values leadership skills more than family orientation, where the first plot resumes the backward induction results for the upper part of the tree and the second for the lower part.

When $\mathrm{E}$ decides to run, then $\mathrm{Y}$ will opt not to run if the founder values leadership skills more than family orientation and path 3 will be played. In that situation Y maximizes his utility by pursing his best option outside the family firm $\left(\mathrm{B}_{\mathrm{Y}}\right)$. If $\mathrm{F}$ values family orientation relatively more than leadership skills, then he will choose $\mathrm{Y}$ when both children compete for the position, therefore if $\mathrm{E}$ runs, $\mathrm{Y}$ will also run as long as $\mathrm{B}_{\mathrm{Y}}<\mathrm{H}_{\mathrm{Y}}-\mathrm{r}-\mathrm{c}_{\mathrm{Y}}$ (paths 3 vs. path 2), as shown in right two plots of Figure 2, where the third plot sums the backward induction results for the upper part of the tree and the forth, for the lower part.

Figure 2: Backward Induction until the node of $Y$

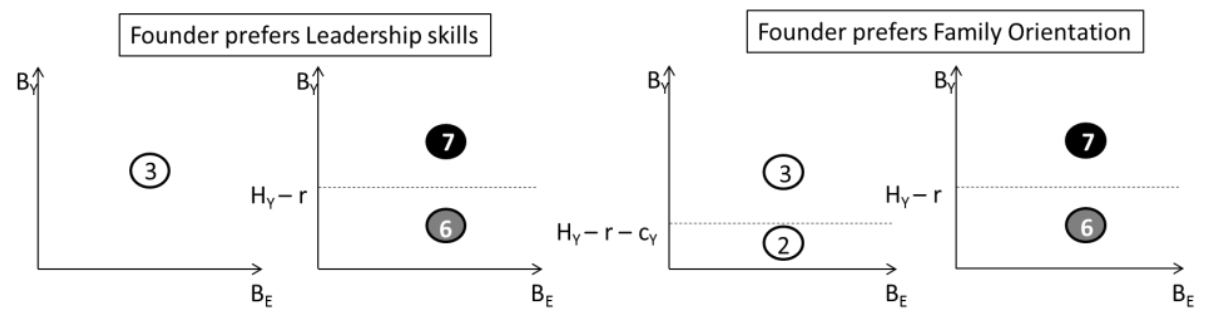

Continuing to employ backward induction we arrive at the root (first node). At this point it is E's turn to make his move. Considering a founder who favors leadership skills more than family orientation, $\mathrm{E}$ anticipates that if he runs, then $\mathrm{Y}$ will not run and so his payoff will be $\mathrm{H}_{\mathrm{E}}-\mathrm{r}$, and if he doesn't run his payoff will be $B_{E}$. Consequently he will run if $H_{E}-r>B_{E}$ and in this case 
the equilibrium path will be path 3 . If he doesn't run, the equilibrium path being 6 or 7 will depend on Y's decision of pursuing his career outside the family firm or not. ${ }^{8}$

Figure 3 illustrates the equilibrium paths and succession outcomes according to the founder's preference.

Figure 3: Equilibrium Paths and Successor Outcomes

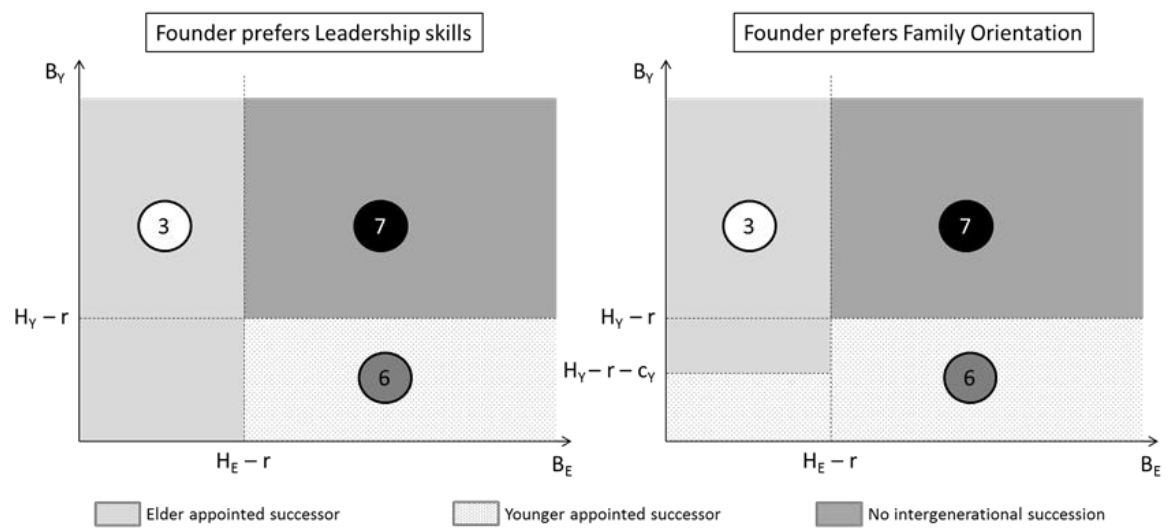

As a result of the founder's preference for leadership skills or family orientation his desired successor will be appointed successor as long as he is available. Consider a founder who relatively values leadership skills more than family orientation (for $\alpha>k \beta ; k=\left(O_{Y}-O_{E}\right) /\left(L_{E}-\right.$ $\left.L_{Y}\right)$ ), then $E$ will be appointed successor as long as he is available (i.e. $H_{E}-r>B_{E}$ ). If $E$ is unavailable (i.e. does not run for the position) then $\mathrm{Y}$ will be successor if he is available. On the other hand, a founder who values family orientation more than leadership skills will prefer his younger child as successor so $\mathrm{Y}$ will be appointed successor as long as he is available, i.e. $\mathrm{B}_{\mathrm{Y}}<\mathrm{H}_{\mathrm{Y}}-\mathrm{r}-\mathrm{c}_{\mathrm{Y}}$. There will be no succession if both children are unavailable, in other words if both prefer to pursue their career outside the family firm $\left(\mathrm{H}_{\mathrm{i}}-\mathrm{r}<\mathrm{B}_{\mathrm{i}}\right)$. When both children run for the CEO position, the successor will be chosen in accordance to the founder's predisposition. Therefore, the elder child will be appointed successor when both children run for

\footnotetext{
${ }^{8}$ In this case the subgame perfect Nash equilibrium strategy, which refers the complete plan of action for each player for each contingency specifying what he will do when he is called to play. When $B_{Y}>H_{Y}-r$ and $B_{E}>H_{E}-r$, the equilibrium path is 7 and the equilibrium strategy is for $\mathrm{F}-\mathrm{F}$ choose $\mathrm{E}$ if $\mathrm{E}$ run and $\mathrm{Y}$ run; $\mathrm{F}$ choose $\mathrm{E}$ if $\mathrm{E}$ run and $\mathrm{Y}$ not run; $\mathrm{F}$ choose $\mathrm{Y}$ if $\mathrm{E}$ not run and $\mathrm{Y}$ run; for $\mathrm{Y}-\mathrm{Y}$ not run if $\mathrm{E}$ run; $\mathrm{Y}$ not run if $\mathrm{E}$ not run; $\mathrm{E}$ not run.
} 
the position $\left(\mathrm{H}_{\mathrm{i}}-\mathrm{r}>\mathrm{B}_{\mathrm{i}}\right)$ if the founder relatively values leadership skills more than family orientation otherwise the younger child will be appointed (i.e. $H_{E}-r>B_{E}$ and $H_{Y}-r-c_{Y}>B_{Y}$ ).

Note, however, that in the particular situation when $\mathrm{F}$ is more inclined to name $\mathrm{Y}$ successor, and $\mathrm{Y}$ is available $\left(\mathrm{H}_{\mathrm{Y}}-\mathrm{r}>\mathrm{B}_{\mathrm{Y}}\right)$, there is still a possibility that $\mathrm{Y}$ is not named successor. This counter intuitive outcome is due to the emotional cost $\mathrm{Y}$ incurs in going against his sibling to secure the successor position. This result not only highlights that all the successor outcomes are not straightforward, but also that the emotional factors have a direct impact on successor selection.

The possibility of intergeneration succession not being secured is dependent on the children's availability to take over the firm's executive control and also on the cost they incur to secure the position. When they have to make a lot of effort to run for the position (high values of $r$ ) then there is higher possibility of the family firm falling victim of the statistics which show that only a minority of family firms continues to the second generation (Aronoff \& Ward, 1995).

The analysis of the impact that changes in the variables can have on the equilibrium results will allow a deeper understanding of the factors at play. The children's endowment of leadership skills and family orientation, allied to the founder's predisposition plays a pivotal role in determining the successor. If, for instance, the elder child completed a MBA degree this would reflect in an increase of $\mathrm{L}_{\mathrm{E}}$. Considering that all other variables remained unchanged, then this could increase his propensity of being appointed successor. The possibility of the elder child becoming the next head of the family firm could also be augmented if the founder became more inclined to having a successor who is more business rather than family oriented (i.e., increase in $\alpha)$.

The cost of conflict resulting from sibling completion $\left(\mathrm{c}_{\mathrm{j}}\right)$ is crucial in the definition of the equilibrium paths but only $c_{Y}$ has a direct impact in terms of successor outcome. If, for some reason, the younger child becomes more averse to conflict this will, all things being equal, diminish his possibilities of becoming successor and, simultaneously, augment his brother's. Therefore, this is a key contributor to whether or not the founder's preferred child is indeed 
named successor. Assuming the founder relatively prefers family orientation, when the emotional cost that $\mathrm{Y}^{9}$ sustains for going head-to-head with his sibling rises, then there is a reduction on the propensity of F's preferred child becoming the successor.

Changes in this emotional cost have no direct impact in terms of ensuring that the firm's executive control remains in the family. Whereas an increase of the value the child places on the firm's continuity, net of the cost of running, ceteris paribus, will enhance the firm's intergenerational sustainability and also raise the propensity of that child being appointed successor.

\section{Collaborative Family - Results \& Discussion}

The subgame perfect Nash equilibrium outcomes result from each player making his decisions in order to maximize his own individual payoff. If we consider a collaborative type of family, as presented by Dyer (1986), where there are shared goals and decisions are made as unit, then the successor outcomes would result from the maximization of the joint payoff of all the players. We denote this outcome as the collaborative family outcome and will refer to it as such herein. The collaborative family outcome can be understood as resulting from the family members cooperating and coordinating their decisions, subordinating their personal goals to the communal good. Unlike the Nash equilibrium where each player maximizes his own individual utility, in the collaborative family outcome, all the players focus on maximizing the aggregate family utility.

The aggregate family payoff is seen as the sum of the payoffs of the founder and both the children, for each path. For instance, the aggregate family payoff for path 2 is: $\pi_{\mathrm{E}}+\pi_{\mathrm{Y}}+\pi_{\mathrm{F}}=$ $\mathrm{B}_{\mathrm{E}}-\mathrm{r}-\mathrm{c}_{\mathrm{E}}+\mathrm{H}_{\mathrm{Y}}-\mathrm{r}-\mathrm{c}_{\mathrm{Y}+} \alpha \mathrm{L}_{\mathrm{Y}}+\beta \mathrm{O}_{\mathrm{Y}}-\mathrm{c}_{\mathrm{F}}$

Table 2 identifies the aggregate family payoffs for each path.

Table 2: Aggregate family payoffs

Paths

Aggregate Family Payoffs

\footnotetext{
${ }^{9}$ Changes in $c_{\mathrm{E}}$ will have impact on successor selection if in the succession game $\mathrm{Y}$ is the first mover.
} 


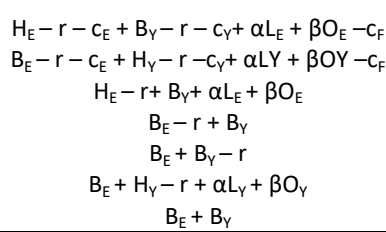

The collaborative family outcome denotes the successor outcomes which will maximize the payoffs of the family as a unit. In other words, it is the optimal outcome if the players acted to maximize the aggregate family payoff. Analyzing Table 2 it is evident that the aggregate family payoff resulting from path 3 is higher than that resulting from path 1 . Similarly, the aggregate family outcome path 6 registers is higher than that resulting from path 2 , as is the outcome of path 7 higher than the ones from path 4 and path 5 . Consequently, we analyze in what conditions path 3, 6 and 7 are the most desirable from a family perspective in order to identify the collaborative family outcome solution. Table 3 highlights that collaborative family outcome may, under certain conditions, differ from the subgame perfect Nash equilibrium.

Table 3: Identification of the parameters set for each collaborative family outcome

\section{More Desirable from Family Stance}

Outcome of Path 3 than Path 6

Outcome of Path3 than Path 7

Outcome of Path 6 than Path 7

\section{Conditions}

$\mathrm{B}_{Y}+\left(\mathrm{H}_{\mathrm{E}}-\mathrm{H}_{Y}\right)+\alpha\left(\mathrm{LE}_{\mathrm{E}}-\mathrm{LY}_{Y}\right)+\beta\left(\mathrm{O}_{\mathrm{E}}-\mathrm{O}_{Y}\right)>\mathrm{B}_{\mathrm{E}}$

$\mathrm{H}_{\mathrm{E}}+\alpha \mathrm{LE}_{\mathrm{E}}+\beta \mathrm{O}_{\mathrm{E}}-\mathrm{r}>\mathrm{B}_{\mathrm{E}}$

$\mathrm{H}_{Y}+\alpha \mathrm{L}_{Y}+\beta \mathrm{O}_{Y}-\mathrm{r}>\mathrm{BY}_{\mathrm{Y}}$

When the decisions are made to maximize the family aggregate payoff rather than the individual payoff of the family members, the successor outcomes differ from the subgame perfect Nash equilibrium results. There are five possible scenarios comparisons (which occur from different set of parameters). Consider first a founder who relatively prefers family orientation to leadership skills (i.e.: $\alpha<\mathrm{k} \beta ; \mathrm{k}=\left(\mathrm{O}_{\mathrm{Y}}-\mathrm{O}_{\mathrm{E}}\right) /\left(\mathrm{L}_{\mathrm{E}}-\mathrm{L}_{\mathrm{Y}}\right)$ ) and that both children equally value heading the family firm $\left(\mathrm{H}_{\mathrm{E}}=\mathrm{H}_{\mathrm{Y}}\right)$ and they both have identical endowments of leadership skills

Comentário [t3]: It should be $\alpha<k \beta$ if the founder prefers family orientation over leadership skills (see the definitions in page 11)

Comentário [S]4]: This has been corrected 
but the younger child is more family oriented than the elder child $\left(\mathrm{L}_{\mathrm{E}}=\mathrm{L}_{\mathrm{Y}}\right.$ and $\left.\mathrm{O}_{\mathrm{Y}}>\mathrm{O}_{\mathrm{E}}\right)$.

Assume also that $\beta\left(\mathrm{O}_{\mathrm{Y}}-\mathrm{O}_{\mathrm{E}}\right)>\mathrm{H}_{\mathrm{Y}}-\mathrm{r}$. Figure 4 illustrates the collaborative family outcomes for this scenario and the solutions comparisons between these outcomes and Nash subgame perfect outcomes.

Figure 4: Collaborative family outcome vs. Nash outcome when founder prefers family orientation: scenario I
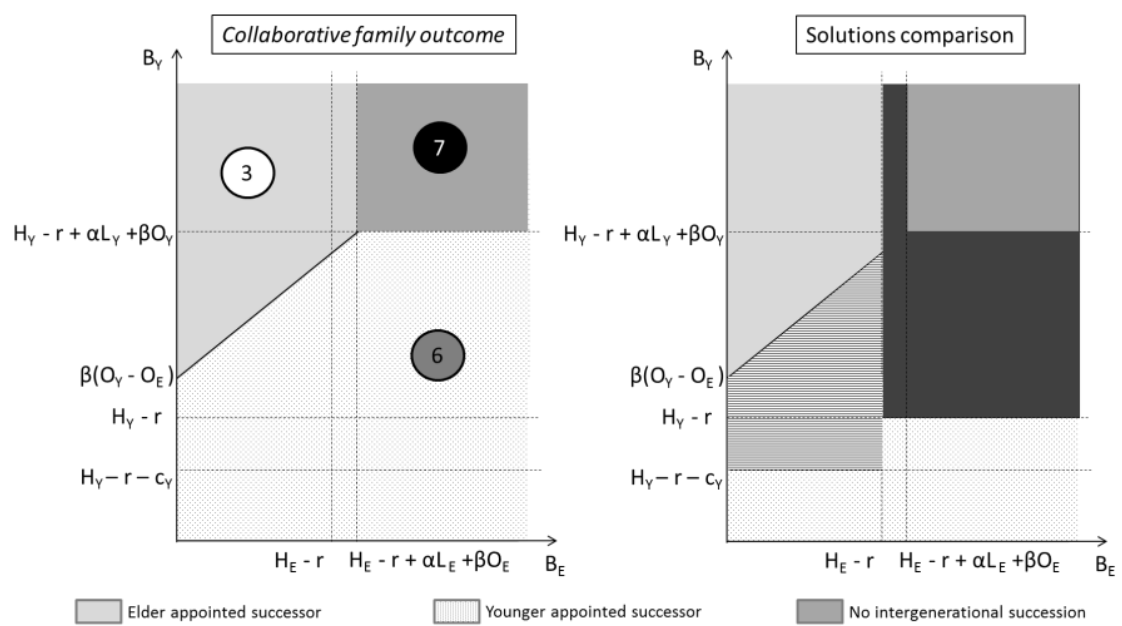

We conclude that when adopting a collaborative family solution, the propensity of intergenerational succession being secured increases. This increase is marked in Figure 4 by the dark L shaped area. The collaborative family outcome solution augments the possibility of the founder's preferred successor, in our example $\mathrm{Y}$, being appointed, comparatively to the subgame perfect Nash outcome. This substitution of $\mathrm{E}$ by $\mathrm{Y}$ is illustrated by the triangular striped area in Figure 4.

If we assume that $\mathrm{H}_{\mathrm{Y}}-\mathrm{r}>\beta\left(\mathrm{O}_{\mathrm{Y}}-\mathrm{O}_{\mathrm{E}}\right)>\mathrm{H}_{\mathrm{Y}}-\mathrm{r}-\mathrm{c}_{\mathrm{Y}}$, then Figure 5 illustrates the collaborative family outcomes for this scenario and the solutions comparisons between these outcomes and Nash subgame perfect outcomes.
Comentário [t5]: Please check this again. This assumption contradicts what is actually shown in in figure 4 , where $\mathrm{H}_{\mathrm{y}}-\mathrm{r}<\beta$ $\left(\mathrm{O}_{Y}-\mathrm{O}_{\mathrm{E}}\right)$.

As far as I understand you have actually three scenarios:

1. $\mathrm{H}_{Y}-\mathrm{r}<\beta\left(\mathrm{O}_{\mathrm{Y}}-\mathrm{O}_{\mathrm{E}}\right)<\mathrm{H}_{\mathrm{Y}}-\mathrm{r}+\alpha \mathrm{L}_{\mathrm{Y}}+\beta \mathrm{O}_{Y}$

2. $\mathrm{H}_{Y}-\mathrm{r}-\mathrm{C}_{Y}<\beta\left(\mathrm{O}_{Y}-\mathrm{O}_{\mathrm{E}}\right)<\mathrm{H}_{Y}-\mathrm{r}$

3. $\beta\left(\mathrm{O}_{Y}-\mathrm{O}_{E}\right)<\mathrm{H}_{Y}-\mathrm{r}-\mathrm{C}_{Y}$

Perhaps it is better to discuss all of the three scenarios.

Comentário [S]6]: This has been corrected and the three scenarios are now discussed

Comentário [t7]: Here you implictly assume that $\mathrm{H}_{\mathrm{E}}-\mathrm{H}_{Y}=0$ and $\alpha\left(\mathrm{L}_{\mathrm{E}}-\mathrm{L}_{Y}\right)=0$, i.e. both family candidates share the same value heading the firm and have the same level of leadership skills. You need to state this assumption in the text otherwise the readers won't know how you draw the figures in Figure 4 without specifying the comparative values of $L_{i}$ and $H_{i}$.

The similar problem arises when you analyze the case where the founder prefers leadership skills over family orientation

(see Figure 6). In that case you seem to assure $\mathrm{H}_{E}-\mathrm{H}_{Y}=0$ and $\beta\left(\mathrm{O}_{E}-\mathrm{O}_{Y}\right)=0$.

Comentário [S]8]: This has been corrected 
Figure 5: Collaborative family outcome vs. Nash outcome when founder prefers family orientation: scenario II

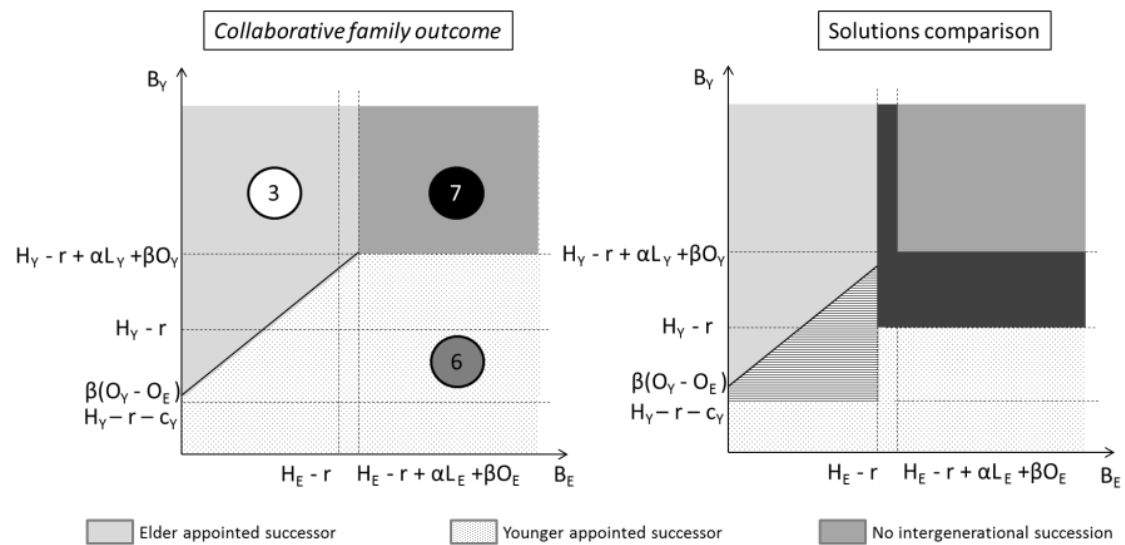

Lastly, if we assume that $\mathrm{H}_{\mathrm{Y}}-\mathrm{r}-\mathrm{c}_{\mathrm{Y}}>\beta\left(\mathrm{O}_{\mathrm{Y}}-\mathrm{O}_{\mathrm{E}}\right)$, then Figure 6 illustrates the collaborative family outcomes for this scenario and also the differences from Nash subgame perfect equilibrium results.

Figure 6: Collaborative family outcome vs. Nash outcome when founder prefers family orientation: scenario III

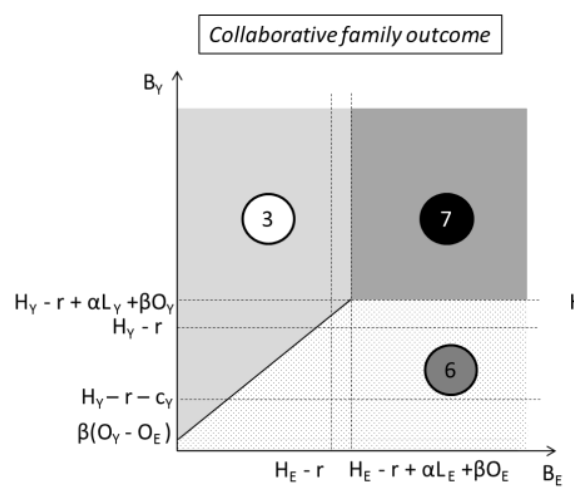

Elder appointed successor

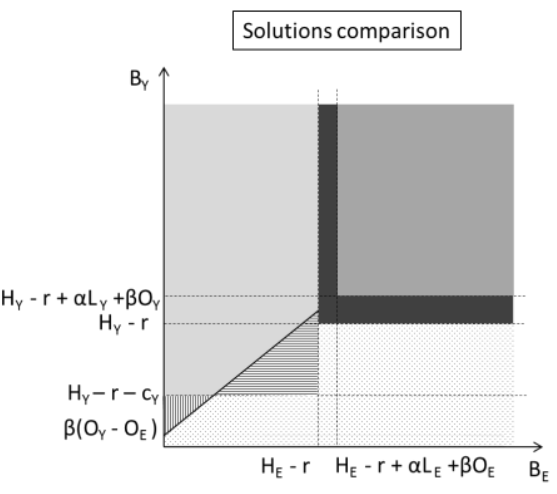

No intergenerational succession

Notice that Figures 5 and 6 reinforce the increase on the propensity of family intergenerational succession being secured (the dark L shaped area) when the players come together and act to 
maximize their aggregate payoff. In Figure 6, there is, also, an enhanced propensity the founder's preferred candidate being appointed (given by the larger striped triangular area) however this is accompanied by an increased possibility of E being named successor instead of Y (given by the smaller striped triangular area).

Finally, Figure 7 shows the collaborative family outcomes and respective comparison to the Nash subgame perfect equilibrium results, for the case of the founder who relatively prefers leadership skills and under the assumption that both children equally value heading the family firm $\left(\mathrm{H}_{\mathrm{E}}=\mathrm{H}_{\mathrm{Y}}\right)$ and that they are equally endowed in terms of family orientation but the elder child has more leadership skills $\left(\mathrm{O}_{\mathrm{E}}=\mathrm{O}_{\mathrm{Y}}\right.$ and $\left.\mathrm{L}_{\mathrm{E}}>\mathrm{L}_{\mathrm{Y}}\right)$. (i.e. $\left.\mid \alpha>k \beta\right)$, for both when $\alpha\left(\mathrm{L}_{\mathrm{E}}-\mathrm{L}_{\mathrm{Y}}\right)<$ $\mathrm{H}_{\mathrm{E}}-\mathrm{r}$ (scenario IV) and $\mathrm{H}_{\mathrm{E}}-\mathrm{r}<\alpha\left(\mathrm{L}_{\mathrm{E}}-\mathrm{L}_{\mathrm{Y}}\right)<\mathrm{H}_{\mathrm{E}}-\mathrm{r}+\alpha \mathrm{L}_{\mathrm{E}}+\beta \mathrm{O}_{\mathrm{E}}$ (scenario $\left.\mathrm{V}\right)$ respectively.

Figure 7: Collaborative family outcome vs. Nash outcome when founder prefers leadership skills: scenario IV and scenario V
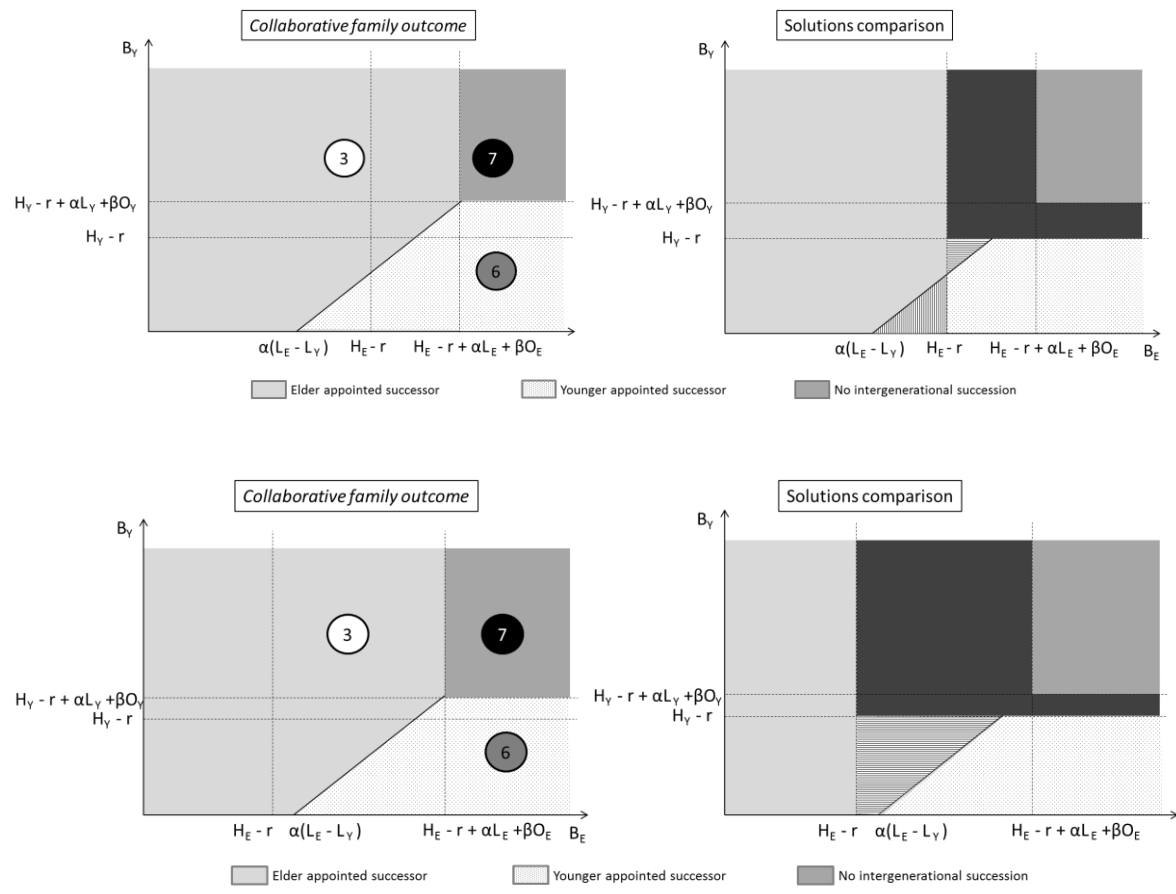

Comentário [t9]: See comment above. This should be $\alpha>\mathrm{k} \beta$.

Comentário [SJ10]: This has been corrected

Comentário [t11]: These inequalities contradict what are shown in Figure 6 , where $\mathrm{H}_{\mathrm{E}}-\mathrm{r}<\alpha\left(\mathrm{L}_{\mathrm{E}}-\mathrm{L}_{Y}\right)<\mathrm{H}_{\mathrm{E}}-r+\alpha \mathrm{L}_{\mathrm{E}}+\beta \mathrm{O}_{\mathrm{E}}$ for scenario III, and and $\alpha\left(L_{E}-L_{Y}\right)<H_{E}-r<H_{E}-r+$ $\alpha L_{E}+\beta O_{E}$ for scenario IV.

Comentário [SJ12]: This has been corrected 
Figure 7, shows that the same pattern of results is present as in the previous scenarios studied, varying only in terms of the dimension of each of the areas. When the founder prefers leadership skills, a raise of the emotional cost of conflict that $\mathrm{Y}$ registers increases the possibility of the founder's preferred successor being appointed, which enlarges the dimension of the striped area. Additionally, when the founder's valuation of his children's abilities and attributes increases $\left(\alpha \mathrm{L}_{\mathrm{i}}+\beta \mathrm{O}_{\mathrm{i}}\right)$, then there is a greater propensity of the intergenerational succession being assured, which augments the dimension of the dark $\mathrm{L}$ shaped areas.

In practical terms, the collaborative family outcome comparisons' analysis shows that when all the family members cooperate and act as a unit with the objective of maximizing the family's aggregate payoff (rather than individual payoffs) then there is greater propensity of the intergenerational succession being assured and increased possibility of the founder's preferred successor being appointed.

\section{CONCLUSION}

It is the enmeshment of the family and the business which is so unique to the family firms and justifies the increased potential for conflict in these firms as they are permeable both to the family and the business. Research shows that conflict is pivotal in the family firm and hampers the firm's performance and compromises family harmony and cohesion (Eddleston \& Kellermans, 2007).

Succession is a critical stage of change and uncertainty which can exasperate conflict in the family firm. Deciding on who will succeed is one of the most important challenges that the family firm faces. The way it is handled, how expectations are managed, and how the final choice is made can lead to conflict especially among competing siblings. The existent literature on conflict in family firms does not pay any special attention to the conflict which can be triggered by the successor race. This paper extends the analysis to better understand the impact that conflict between siblings has in terms of successor outcomes. 
The article builds on the use of game theory to study family firm succession and contributes by highlighting the importance of emotional factors in determining the successor. The results show that the successor outcome will depend on the founder's preference and also emphasize the importance of the cost of conflict. The findings demonstrate that the emotional cost of conflict which results from sibling competition is essential in the selection of the successor. The higher the emotional cost that a child sustains for competing against his sibling, the lower the propensity of that child being appointed successor, even if he is indeed the founder's preferred candidate.

The article introduces the collaborative family outcome which identifies the successor outcome when the family members come together in order to maximize the family's utility. Our results show that in that case, in contrast to the subgame perfect Nash equilibrium results, there is a greater propensity of ensuring family firm intergeneration continuity, as well as an enhanced possibility of the founder's preferred child being named successor.

The collaborative family outcome analysis highlights the importance of founders, practitioners and consultants working to promote greater cooperation and more cohesiveness between family members, as this will help ensure family firm intergenerational succession.

Furthermore, it is conceivable that given the impact it has on family firm continuity it will also play a role in terms of value creation. As per, Kammerlander, Sieger, Voordeckers and Zellweger (2015) suggestion of using an integrated focus, the collaborative family outcome presents an interesting avenue for future research in terms of family firm value creation.

Additionally, the discussion of the impact of adopting the collaborative family outcome might also focus on the performance in family firms. In line with Gallucci, Santulli and Calabró (2015), there have been many attempts to catch the effect of the unique resource - family involvement - on family firm performance. Also, Wagner et al. (2015) present the results of a meta-analysis of the financial performance of family firm. Thus extending their analysis by investigating how employing a collaborative family outcome moderates the relationship between family firm and performance is a promising research opportunity. 
Our approach focused on first generation transfers, however second or third generation transfers imply more potential successors and more possible sources of conflict which may be an opportunity for future research. Another opportunity would be to use cooperative game theory to study the incentive for potential successors to collude in order to attain a certain successor outcome. Last but not least, would be to focus on studying the impact that a founder adopting a more proactive approach and inviting one of his children could have in terms of both Nash and collaborative family outcomes.

Our paper strengthens the importance of game theory as a tool to rationalize and understand family firm succession analysis. We explore new frontiers by including emotional factors and by studying the collaborative family outcome. The use of game theory promises to shed new light on research in family firm succession when allied to empirical data, and employing experimental and behavioral techniques.

\section{REFERENCES}

Aronoff, C. E., \& Ward, J. L. (1995). Family-owned businesses: A thing of the past or a model for the future? Family Business Review, 2, 121-130.

Astrachan, J. H., \& Jaskiewicz, P. (2008). Emotional Returns and Emotional Costs in Privately Held Family Businesses: Advancing Traditional Business Valuation. Family Business Review, 21(2), 139-149.

Avloniti, A., Iatridou, A., Kaloupsis, I., \& Vozikis, G.S. (2014). Sibling rivalry: implications for the family business succession process. International Entrepreneurship Management Journal, 10, 661-678.

Bjuggren, P., \& Sund, L. (2001). Strategic decision making in intergenerational successions of small-and medium-size family-owned businesses. Family Business Review, 14(1), 1124.

Blumentritt, T., Mathews, T., \& Marchisio, G. (2013). Game Theory and Family Business 
Succession: An Introduction. Family Business Review, 26(1), 51-67.

Burkat, M.F., Panunzi, F. \& Shleifer, A. (2003). Family firm. Journal of Finance, 58, $2167-$ 2202.

Cater J. J. \& Justis, R. (2009). The development of successors from followers to leaders in small family firms. Family Business Review, 22(2), 109-124.

Chrisman, J. J., Chua, J. H., Pearson, A. W., \& Barnett, T. (2012). Family Involvement, Family Influence, and Family-Centered Non-Economic Goals in Small Firms. Entrepreneurship Theory and Practice, 36(2), 267-293.

DeNoble, A., Ehrlich, S. \& Singh, G. (2007). Toward the development of a family business selfefficacy scale: A resource-based perspective. Family Business Review, 20(2), 127-140.

Distelberg, B., \& Sorenson, R. L. (2009). Updating systems concepts in family businesses: A focus on values, resource flows, and adaptability. Family Business Review, 22(1), 6581.

Dyer, W. G. (1986). Cultural change in family firms: Anticipating and managing business and family transitions. San Francisco, Jossey-Bass.

Eddleston, K. A., \& Kellermanns, F. W. (2007). Destructive and productive family relationships: A stewardship theory perspective. Journal of Business Venturing, 22(4), $545-565$.

Friedman, S. D. (1991). Sibling relationships and intergenerational succession in family firms. Family Business Review, 4 (3), 3-20.

Gallucci, C., Santulli, R., \& Andrea, C. (2015). Does family involvement foster or hinder firm performance? The missing role of family-based branding strategies. Journal of Family Business Strategy, 6(3), 155-165.

Gómez-Mejía, L. R., Haynes, K. T., Núñez-Nickel, M., Jacobson, K. J., \& Moyano-Fuentes, J. (2007). Socioemotional wealth and business risks in family-controlled firms: Evidence from Spanish olive oil mills. Administrative Science Quarterly, 52(1), 106-137.

Gómez-Mejía, L. R., Núñez-Nickel, M. \& Guiterrez, I. (2001). The role of family ties in agency contracts. Academy of Management Journal, 44, 81-95. 
Grant, G. \& Nicholson, N. (2008). Family Wars: Classic Conflicts in Family Business and How to Deal with Them. London: Kogan Page

Griffeth, R. W., Allen, D. G., \& Barrett, R. (2006). Integration of family-owned business succession with turnover and life cycle models: development of a successor retention process model. Human Resources Management Review, 16, 490-507.

Habbershon, T. G., \& Williams, M. (1999). A resource-based framework for assessing the strategic advantage of family firms. Family Business Review, 12 (1), 1-25.

Harvey, M. \& Evans, R.E. (1994). Family business and multiple level of conflict. Family Business Review 7(4), 331-348.

Jayantilal, S., Palacios, T. B., \& Jorge, S. F. (2015). Cultural dimension of Indian family firmsimpact on successor selection. Problems and Perspectives in Management, 13(3), 116123.

Kammerlander, N., Sieger, P., Voordeckers, W., \& Zellweger,T. (2015). Value creation in family firms: A model of fit, Journal of Family Business Strategy, 6(2), 63-72.

Klein, S. B., \& Kellermanns, F. W. (2008). Editor's Notes. Family Business Review, 21(2), $121-125$.

Kreps, D. M. (1990). Game Theory and Economic Modeling. Oxford: Clarendon Press.

Lee, K. S., Lim, G. H., \& Lim, W. S. (2003). Family business succession: Appropriation risk and choice of successor. Academy of Management Review, 28(4), 657-666.

Lumpkin, G.T., Martin, W., \& Vaughn, M. (2008). Family Orientation: Individual-Level Influences on Family Firm Outcomes. Family Business Review, 21(2), 127-138.

Mathews, T., \& Blumentritt, T. (2015). A sequential choice model of family business succession. Small Business Economics, 45(1), 15-37.

Michael-Tsabari, N., \& Weiss, D. (2013). Communication Traps: Applying Game Theory to Succession in Family Firms. Family Business Review 20(10), 1-15.

Miller, D., Steier, L., \& Le Breton-Miller, I. (2003). Lost in time: intergenerational succession, change, and failure in family business. Journal of Business Venturing, 18(4), 513-531.

Motwani, J., Levenburg, N., Schwarz, T. \& Blanson, C. (2006). Succession planning is SME's - 
An empirical analysis. International Small Business Journal, 24(5), 471-495.

Pieper, T.M., \& Klein, S.B. (2007). The Bulleye: A system approach to modeling family firms Family Business Review 20(4), 301-319.

Sorenson, R. (1999). Conflict management strategies used by successful family businesses. Family Business Review, 12(4), 133-146.

Wagner, D., Block, J., Miller, D., Schwens, C. \& Xi, G. (2015). A meta-analysis of the financial performance of family firms: Another attempt. Journal of Family Business Strategy, 6(1), 3-13.

Waldman, D. A., Siegel, D. \& Javidan, M. (2006). Components of transformational leadership and corporate social responsibility. Journal of Management Studies, 43(8), 1703-1725.

Zellweger, T. M., \& Astrachan, J. H. (2008). On the Emotional Value of Owning a Firm. Family Business Review, 21(4), 347-363. 